\title{
Faktor - Faktor Yang Mempengaruhi Kebijakan Dividen Pada Perusahaan Manufaktur Yang Terdaftar Di Bursa Efek Indonesia Periode Tahun 2012-2016
}

\author{
GLORIA JULIANITA SENDOW ${ }^{1}$, GRACE B. NANGOI ${ }^{2}$, WINSTON PONTOH ${ }^{3}$ \\ ${ }^{1,2,3}$ Program Magister Akuntansi, Fakultas Ekonomi dan Bisnis Universitas Sam Ratulangi \\ e-mail: sendowgloria@gmail.com ${ }^{1}$,gracebn@yahoo.com ${ }^{2}$,Winston_pontoh@yahoo.com ${ }^{3}$
}

\begin{abstract}
This study aims to determine the effect of Stock Price (Closing Price), Profitability (ROA), Retained Earnings to Total Assets (RETA), Liquidity (CR) and Debt (DAR) on Dividend Policy in Indonesian manufacturing company during 2012 to2016. 28 companies were chosen as samples. They were selected by purposive sampling method. This study obtained those companies' annual reports from their official websites. Hypotheses were tested by using logistic regression method. The results show that the first hypothesis of stock price does not affect Dividend policy $(0.156>0.05)$; the second hypothesis is profitability, it affects Dividend policy $(0.003<0.005$; the third hypothesis is RETA, it does not affect Dividend Policy $(0.131>0.05)$, the fourth one is Liquidity, it does not affect Dividend policy (0.888 > 0.05); and the fifth hypothesis is Debt (DAR), it does not affect Dividend Policy (0.365 > $0.05)$.
\end{abstract}

Keywords: Dividend Policy, Stock Price, Profitability, RETA, Liquidity, Debt.

\begin{abstract}
Abstrak. Penelitian ini bertujuan untuk mengetahui pengaruh Harga Saham (Closing Price), Profitabilitas (ROA), Retained Earnings to Total Assets (RETA), Likuiditas (CR) dan Hutang (DAR) terhadap Kebijakan Dividen pada perusahaan manufaktur yang terdaftar di BEI pada tahun 2012-2016. Pemilihan sampel dengan menggunakan metode purposive sampling sehingga diperoleh jumlah sampel sebanyak 28 perusahaan. Penelitian ini menggunakan data sekunder yaitu laporan tahunan (annual report) yang diperoleh melalui website resmi perusahaan. Pengujian hipotesis dilakukan dengan menggunakan metode regresi logistik. Hasil penelitian menunjukkan bahwa hipotesis pertama yaitu harga saham tidak mempengaruhi kebijakan dividen $(0.156>0.05)$, hipotesis kedua yaitu profitabilitas mempengaruhi kebijakan dividen $(0.003<0.05)$, hipotesis ketiga yaitu RETA tidak mempengaruhi kebijakan dividen $(0.131>0.05)$, hipotesis keempat yaitu likuiditas tidak mempengaruhi kebijakan dividen $(0.888>$ $0.05)$ dan hipotesis ke lima yaitu hutang tidak mempengaruhi kebijakan dividen $(0.365>0.05)$.
\end{abstract}

Kata Kunci: Kebijakan dividen, harga saham, profitabilitas, RETA, likuiditas, hutang

\section{Pendahuluan}

Tujuan utama seorang investor dalam menanamkan dananya adalah untuk memperoleh pendapatan (return), baik berupa pendapatan dividen (dividend yield) maupun pendapatan dari selisih harga jual saham terhadap harga belinya (capital gain). Dengan kata lain dapat dikatakan bahwa dividen yang diperoleh merupakan salah satu alasan investor untuk menanamkan dananya pada suatu perusahaan. Dividen merupakan salah satu motivasi untuk menanamkan dana di pasar modal (market security) bagi investor. Selain itu, investor dapat mengevaluasi kinerja perusahaan dengan menilai besarnya dividen yang dibagikan. Begitu pentingnya kebijakan dividen terhadap banyak pihak, sehingga faktor-faktor yang mempengaruhi kebijakan dividen berdasarkan informasi keuangan yang dipublikasikan oleh perusahaan perlu untuk diidentifikasi.

Harga saham merupakan nilai dari suatu saham yang terbentuk di pasar surat berharga sebagai akibat dari penawaran dan permintaan yang ada. Perusahaan yang ingin menjaga tingkat perusahaan yang tinggi cenderung untuk membagikan dividen tinggi. Jika nilai perusahaan tinggi harga saham akan naik, sehingga banyak investor akan tertarik menanamkan modal pada perusahaan tersebut, dengan begitu perusahaan memiliki profit yang besar yang memungkinkan untuk membagikan dividen.

Profitabilitas merupakan kemampuan perusahaan untuk memperoleh laba atau profit, sehingga mempunyai pengaruh pada kebijakan dividen. Jika suatu perusahaan mempunyai tingkat profitabilitas yang tinggi, maka perusahaan tersebut mendapatkan laba yang tinggi pula dan pada akhirnya laba yang tersedia untuk dibagikan kepada para pemegang saham akan semakin besar. 
Faktor lainnya yang mempengaruhi kebijakan dividen adalah Retained Earnings to Total Assets (RETA). Perusahaan yang memiliki kesempatan bertumbuh lebih tinggi cenderung menahan labanya untuk diinvestasikan kembali dalam kegiatan operasional perusahaan. Sedangkan perusahaan yang saldo laba ditahannya sudah tinggi, biasanya merupakan perusahaan yang berada dalam tahap matang, sudah mampu menghasilkan kas namun dengan kesempatan bertumbuhnya yang lebih rendah, sehingga merupakan kandidat yang baik untuk mendistribusikan kas kepada pemegang saham dalam bentuk dividen.

Likuiditas merupakan kemampuan perusahaan untuk memenuhi kewajiban finansial yang berjangka pendek tepat waktunya Keadaan seperti itu membuat investor akan tertarik menanamkan modalnya untuk membagikan keuntungan berupa dividen. Rasio hutang bisa berarti buruk pada situasi ekonomi sulit dan suku bunga tinggi, dimana perusahaan yang memiliki rasio hutang yang tinggi dapat mengalami masalah keuangan, namun selama ekonomi baik dan suku bunga rendah maka dapat meningkatkan keuntungan.

Berdasarkan latar belakang yang telah diuraikan diatas, maka dapat dirumuskan permasalahan penelitian sebagai berikut:

1. Apakah harga saham berpengaruh terhadap kebijakan dividen pada Perusahaan Manufaktur di Bursa Efek Indonesia Periode 2012 - 2016 ?

2. Apakah profitabilitas berpengaruh terhadap kebijakan dividen pada Perusahaan Manufaktur di Bursa Efek Indonesia Periode 2012 - 2016?

3. Apakah RETA berpengaruh terhadap kebijakan dividen pada Perusahaan Manufaktur di Bursa Efek Indonesia Periode 2012 - 2016?

4. Apakah likuiditas berpengaruh terhadap kebijakan dividen pada Perusahaan Manufaktur di Bursa Efek Indonesia Periode 2012 - 2016 ?

5. Apakah hutang berpengaruh terhadap kebijakan dividen pada Perusahaan Manufaktur di Bursa Efek Indonesia Periode 2012 - 2016 ?

Tujuan Penelitian terdiri dari 1) Untuk mengetahui pengaruh harga saham terhadap kebijakan dividen pada Perusahaan Manufaktur di Bursa Efek Indonesia Periode 2012 - 2016; 2)Untuk mengetahui pengaruh profitabilitas terhadap kebijakan dividen pada Perusahaan Manufaktur di Bursa Efek Indonesia Periode 2012 - 2016; 3) Untuk mengetahui pengaruh RETA terhadap kebijakan dividen pada Perusahaan Manufaktur di Bursa Efek Indonesia Periode 2012 - 2016; 4) Untuk mengetahui pengaruh likuiditas terhadap kebijakan dividen pada Perusahaan Manufaktur di Bursa Efek Indonesia Periode 2012 - 2016, Untuk mengetahui pengaruh hutang terhadap kebijakan dividen pada Perusahaan Manufaktur di Bursa Efek Indonesia Periode 2012 - 2016.

\section{Tinjauan Pustaka}

\section{Teori Katering (Catering Theory)}

Baker dan Wurgler (2004a) menyatakan bahwa, intisari dari teori katering adalah para manajer entitas akan memenuhi permintaan dividen dari investor, akan tetapi keputusannya adalah terbatas pada pembayaran dan bukan pada jumlah dividen yang akan dibayarkan. Dengan kata lain, perusahaan harus membayar dividen ketika investor menilai terlalu tinggi saham di pasar, sehingga memiliki implikasi bahwa membayar dividen jika harga saham naik.

\section{Life Cycle Theory}

De Angelo, De Angelo dan Stulz (2006) mengungkapkan mengenai teori ini bahwa siklus hidup perusahaan telah banyak diaplikasikan dalam berbagai literatur mengenai organisasi dan strategi bisnis. Model siklus hidup perusahaan menjelaskan bahwa perusahaan akan berkembang dan berpindah dari satu tahapan perkembangan ke tahapan lainnya. Selain itu,perusahaan akan mengikuti suatu pola yang dapat diprediksi dan ditandai dengan berbagai tahapan perkembangan. Damodaran (2001:511) membagi lima tahap siklus hidup perusahaan terdiri dari Tahap Awal (Start-Up), Tahap Ekspansi (Expansion), Tahap Pertumbuhan (High growth), Tahap Kedewasaan (Mature Growth), dan Tahap Penurunan (Decline). 


\section{Free Cash Flow Theory}

Menurut Jensen dan Ross et al dalam Rosdini (2007) menyatakan bahwa free cash flow yaitu kas perusahaan yang dapat didistribusi kepada pemegang saham yang tidak digunakan untuk modal kerja atau investasi pada asset tetap. Free cash flow menunjukkan gambaran bagi investor bahwa dividen yang dibagikan oleh perusahaan tidak sekedar strategi menyiasati pasar dengan maksud meningkatkan nilai perusahaan. Besar kecil dividen yang dibayarkan kepada pemegang saham tergantung pada kebijakan dividen masing-masing perusahaan dan dilakukan berdasarkan pertimbangan berbagai faktor. Kebijakan dividen suatu perusahaan dikatakan dipengaruhi oleh Free cash flow karena menggambarkan tingkat fleksibilitas keuangan perusahaan.

\section{Teori Kebijakan Dividen}

Dividen adalah pembagian kepada para pemegang saham dari suatu perusahaan secara proporsional sesuai dengan jumlah lembar saham yang dipegang oleh masing-masing pemilik (Stice, et al. 2004). Besar kecilnya dividen yang dibayarkan kepada pemegang saham tergantung dari kebijakan dividen masing-masing perusahaan dan ditentukan dalam Rapat Umum Pemegang Saham (RUPS).

Kebijakan Dividen merupakan bagian yang menyatu dengan keputusan pendanaan perusahaan. Rasio pembayaran dividen (dividend pay out ratio) menentukan jumlah laba yang dapat ditahan sebagai sumber pendanaan. Semakin besar laba ditahan semakin sedikit jumlah laba yang dialokasikan untuk pembayaran dividen. Alokasi penentuan laba sebagai laba ditahan dan pembayaran dividen merupakan aspek utama dalam kebijakan dividen (Keown, 2000: 496).

\section{Pengaruh Harga Saham Terhadap Kebijakan Dividen}

Harga saham adalah nilai suatu saham yang mencerminkan kekayaan perusahaan untuk mengeluarkan saham, di mana perubahan atau fluktuasinya sangat ditentukan penawaran dan permintaan yang terjadi di pasar bursa (Husnan dan Squad, 2001). Dalam penelitian Wonggo (2016) yang meneliti pengaruh harga saham terhadap kebijakan deviden dengan hasil penelitian bahwa harga saham berpengaruh terhadap kebijakan deviden. Secara teori harga saham berkorelasi positif terhadap kebijakan dividen, dimana harga saham masa lalu mempengaruhi kebijakan dividen. Secara logic hubungannya dengan dividen yaitu jika nilai perusahaan tinggi, harga saham tinggi maka perusahaan cenderung untuk membagikan dividen. Jadi perusahaan yang ingin menjaga tingkat perusahaan tinggi maka kecenderungan membagikan dividen semakin meningkat.

\section{Pengaruh Profitabilitas Terhadap Kebijakan Dividen}

Mamduh M Hanafi (2004) menyatakan bahwa terdapat pengaruh profitabilitas dengan kebijakan dividen, perusahaan yang mempunyai aliran kas atau profitabilitas yang baik bisa membayar dividen atau meningkatkan dividen. Sebaliknya jika profitabilitas buruk tidak bisa membayar dividen atau menurunkan dividen. Sehingga dapat menyimpulkan bahwa profitabilitas berpengaruh positif dan signifikan terhadap kebijakan dividen. Fama dan French (2002) menemukan bahwa, profitabilitas (diproksi rasio laba operasi atas total asset) memiliki pengaruh positif signifikan terhadap pembayaran dividen. Dimana perusahaan yang membagikan dividen cenderung perusahaan besar, memiliki profitabilitas tinggi dengan kesempatan bertumbuh, sedangkan perusahaan yang profitabilitasnya rendah namun kesempatan bertumbuh tinggi dengan pengeluaran investasi yang melebihi pendapatannya memilih untuk menahan labanya dan tidak membagikan dividen.

\section{Pengaruh Retained Earnings to Total Asset (RETA) Terhadap Kebijakan Dividen}

De Angelo et al (2006) menunjukkan proporsi RETA memiliki hubungan positif dengan kemungkinan pembayaran dividen. Perusahaan dengan saldo laba ditahan yang rendah akan lebih ideal dikategorikan sebagai perusahaan yang cenderung membagikan dividen. Fama dan French (2002) menjelaskan bahwa financial life cycle mempengaruhi kebijakan dividen di perusahaan. Teori ini menjelaskan bahwa perusahaan yang memiliki kesempatan bertumbuh lebih tinggi cenderung menahan labanya untuk diinvestasikan kembali (Reinvestment) dalam kegiatan operasional perusahaan. Sedangkan 
perusahaan yang saldo laba ditahannya sudah tinggi, biasanya merupakan perusahaan yang berada dalam tahap matang, sehingga merupakan kandidat yang baik untuk mendistribusikan kas kepada pemegang saham dalam bentuk dividen.

\section{Pengaruh Likuiditas Terhadap Kebijakan Dividen}

Sartono (2001:114) menyatakan tingkat likuiditas yang tinggi dapat menggambarkan kinerja perusahaan yang baik karena dengan tingkat likuiditas yang baik perusahaan akan lebih mudah untuk memenuhi kewajiban pembayaran dividen. Dalam hal ini berarti, semakin tinggi tingkat likuiditas semakin besar pula tingkat kemampuan perusahan untuk membayarkan dividen kepada para pemegang saham. Menurut Keown et al (2001:621) likuiditas perusahaan menunjukkan kemampuan perusahaan mendanai operasional perusahaan dan melunasi kewajiban jangka pendeknya. Posisi likuiditas perusahaan pada kemampuan pembayaran dividen sangat berpengaruh karena dividen dibayarkan dengan kas dan tidak dengan laba ditahan, perusahaan harus memiliki kas tersedia untuk pembayaran dividen. Sesuai dengan teori free cash flow yang dikemukakan Jensen dan Ross et al dalam Rosdini (2007) yaitu kas perusahaan yang dapat didistribusi kepada pemegang saham yang tidak digunakan untuk modal kerja atau investasi pada asset tetap. Oleh karena itu perusahaan yang memiliki likuiditas baik maka kemungkinan pembayaran dividen lebih baik pula.

\section{Pengaruh Hutang Terhadap Kebijakan Dividen}

De Angelo dan De Angelo (1990) menjelaskan bahwa, munculnya perjanjian hutang akan mempengaruhi kebijakan dividen sebuah entitas bisnis, akan tetapi di lain sisi, munculnya utang dalam sebuah entitas bisnis bukan merupakan factor utama dalam pengurangan dividen. Menurut Modigliani dan Miller (1958), ada kemungkinan hubungan antara kebijakan dividen dan kebijakan hutang. Tapi Acharya, Almeida, dan Campello (2007) menemukan rasio utang tersebut memiliki pengaruh negatif yang signifikan terhadap pembayaran dividen yang memberikan implikasi masing-masing kenaikan utang akan menurunkan pembayaran dividen. Karena perusahaan menggunakan hutang sebagai dana eksternal, maka perusahaan akan menghadapi konsekuensi membayar bunga pinjaman yang berdampak pada penurunan laba perusahaan untuk tahun berjalan. Teori free cash flow menurut Brigham dan Houston (2010:109) adalah arus kas yang benar-benar tersedia untuk dibayarkan kepada seluruh investor (pemegang saham dan pemilik utang) setelah perusahaan menempatkan seluruh investasinya pada aktiva tetap, produk-produk baru dan modal kerja yang dibutuhkan untuk mempertahankan operasi yang sedang berjalan.

\section{Gambar 1.Kerangka Pemikiran}

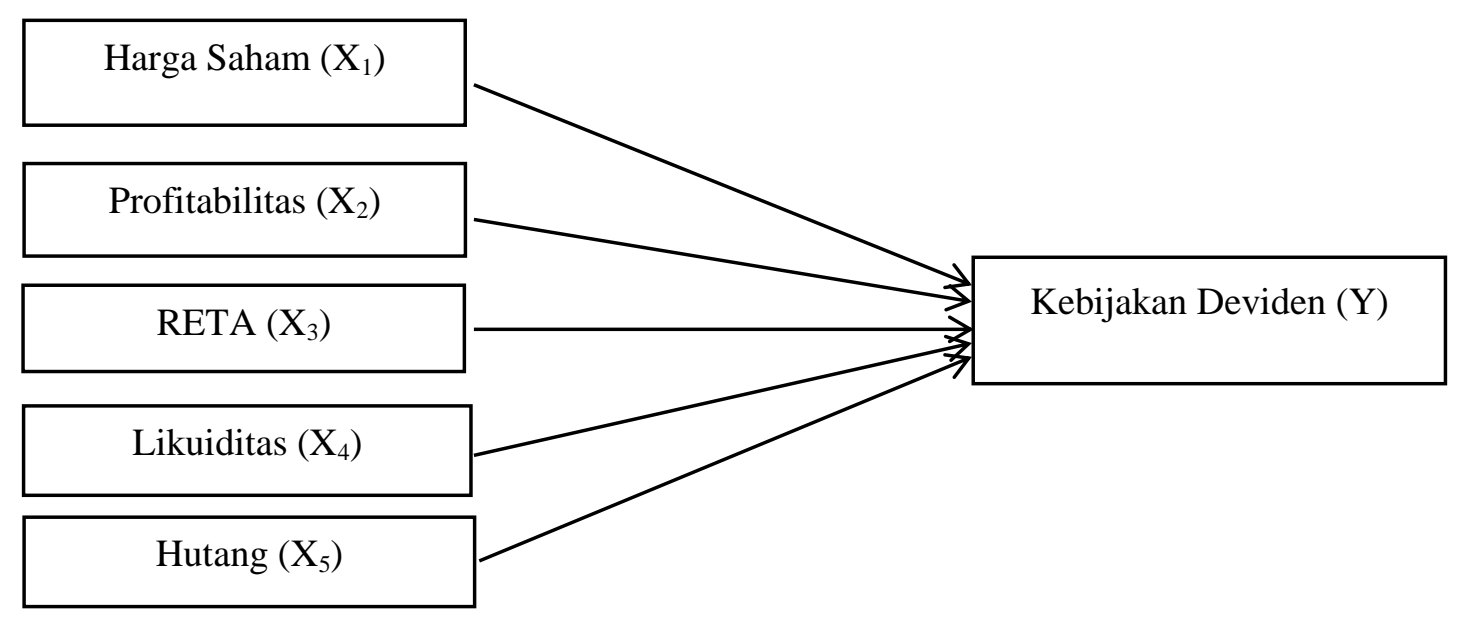

Sumber: Data Hasil Olahan (2017) 


\section{Metode Penelitian \\ Jenis Penelitian}

Sugiyono (2012:13) menyatakan bahwa metode penelitian kuantitatif dapat diartikan sebagai metode penelitian yang berlandaskan pada filsafat positivisme, digunakan untuk meneliti pada populasi atau sampel tertentu, teknik pengambilan sampel pada umumnya dilakukan secara random, pengumpulan data menggunakan instrumen penelitian, analisis data bersifat kuantitatif/statistik dengan tujuan untuk menguji hipotesis yang telah ditetapkan.

\section{Populasi dan Sampel}

Sugiyono (2012:115), populasi adalah wilayah generalisasi yang terdiri atas: obyek/subyek yang mempunyai kualitas dan karakteristik tertentu yang ditetapkan oleh peneliti untuk dipelajari dan kemudian ditarik kesimpulannya. Populasi dari penelitian ini adalah perusahaan manufaktur terdiri sektor industri dasar dan kimia, sektor aneka industri, sektor industri barang dan konsumsi.

Sugiyono (2016:144), purposive sampling adalah teknik pengambilan sampel sumber data dengan pertimbangan tertentu. Berdasarkan definisi terkait purposive sampling maka pertimbangan atau kriteria yang ditentukan dalam penelitian ini adalah sebagai berikut:

1. Perusahaan manufaktur yang mempublikasikan annual report secara lengkap selama periode penelitian yaitu tahun 2012-2016, annual report harus dipublikasikan secara lengkap untuk menghindari terjadinya Perusahaan manufaktur yang mempublikasikan annual report secara lengkap selama periode penelitian yaitu tahun 2012-2016, annual report harus dipublikasikan secara lengkap untuk menghindari terjadinya bias pada saat pengolahan data.

2. Laporan keuangan tahunan yang diterbitkan harus mengalami laba. Hal ini dilakukan untuk menghindari data yang minus yang berarti bahwa laporan tahunan tersebut menandakan perusahaan mengalami kerugian, data yang minus menghasilkan output yang tidak signifikan.

3. Perusahaan manufaktur yang mengungkapkan informasi tentang aktivitas kebijakan dividen dalam website perusahaan maupun dalam annual report, hal ini untuk menunjang penelitian terkait dengan penelitian yang harus dilaksanakan.

Oleh karena itu, sesuai dengan kriteria sampel maka terdapat n sebanyak seratus lima belas (115) yang memenuhi kriteria yang diambil sebagai sampel dari dua puluh delapan perusahaan manufaktur yang terdaftar di Bursa Efek Indonesia, sampel diambil dari laporan tahunan (annual report) perusahaan.

\section{Data dan Sumber Data}

Data merupakan fakta empiris yang sudah dikumpulkan oleh peneliti untuk memecahkan masalah/menjawab penelitian. Sumber data dalam penelitian ini adalah sumber data sekunder, data sekunder merupakan sumber yang tidak langsung memberikan data kepada pengumpul data (Sugiyono, 2012:222).

\section{Definisi Operasional dan Pengukuran Variabel}

1) Variabel Terikat (Dependent Variable): Kebijakan Dividen adalah jumlah pembayaran dividen, dimana variable akan dikategorikan dengan variable dummy berdasarkan jenis: perusahaan yang tidak membayar dividen 0 tahun (Div0) dan perusahaan yang membayar dividen untuk 1 tahun (Div1), akan menjadi variable referensi/pembanding.

2) Variabel Bebas (Independent Variable): Harga Saham $\left(\mathrm{X}_{1}\right)$ yang dimaksud dalam penelitian ini adalah harga saham pada saat penutupan (closing price), Profitabilitas $\left(\mathrm{X}_{2}\right)$ ROA merupakan perbandingan antara laba bersih setelah pajak dengan total aktiva, Retained Earnings to Total Assets (RETA) $\left(\mathrm{X}_{3}\right)$ untuk mengukur kemampuan perusahaan untuk menghasilkan laba ditahan dari total aktiva perusahaan, Likuiditas $\left(\mathrm{X}_{4}\right)$ diukur dengan current ratio adalah rasio yang membandingkan antara aktiva lancar yang dimiliki perusahaan dengan hutang jangka pendek, Hutang $\left(\mathrm{X}_{5}\right)$ Rasio yang digunakan untuk mengukur variabel hutang adalah rasio Debt to assets ratio (DAR). 


\section{Hasil Penelitian Dan Pembahasan}

Statistik deskriptif dalam penelitian ini menjabarkan hasil perhitungan nilai minimum, nilai maksimum, nilai rata-rata (mean), dan standar deviasi dari Kebijakan Dividen, Harga Saham, Profitabilitas, RETA, Likuiditas dan Hutang. Nilai minimum merupakan nilai terendah dari variabel, sedangkan nilai maksimum merupakan nilai tertinggi dari setiap variabel yang diteliti. Nilai mean merupakan nilai rata-rata dari setiap variabel yang diteliti. Standar deviasi merupakan sebaran data yang digunakan dalam penelitian yang mencerminkan data itu heterogen atau homogen yang sifatnya fluktuatif.

Tabel 1. Statistik Deskriptif Variabel Penelitian

\begin{tabular}{|l|r|r|r|r|r|}
\hline & $\mathrm{N}$ & Minimum & Maximum & Mean & $\begin{array}{r}\text { Std. } \\
\text { Deviation }\end{array}$ \\
\hline Harga Saham & 115 & 1,70 & 5,38 & 3,1666 &, 70008 \\
Profitabilitas & 115 &, 03 & 1,87 &, 8908 &, 34636 \\
RETA & 115 &, 30 & 2,12 & 1,4245 &, 35635 \\
Likuiditas & 115 & 1,71 & 3,14 & 2,3502 &, 33554 \\
Hutang & 115 &, 07 & 1,16 &, 4287 &, 21069 \\
Kebijakan Dividen & 115 &, 00 & 1,00 &, 5217 &, 50171 \\
Valid N (listwise) & 115 & & & & \\
\hline
\end{tabular}

Sumber: Data Hasil Olahan SPSS 20 (2017)

Berdasarkan tabel 1, sesuai dengan periode penelitian yaitu 5 tahun yang menunjukkan bahwa variabel kebijakan dividen diperoleh nilai rata-rata 0.5217 dengan standar deviasi 0.50171 dimana nilai standar deviasi lebih kecil daripada nilai rata-rata yang menunjukkan bahwa kebijakan dividen pada perusahaan manufaktur di Indonesia pada tahun 2012-2016 memiliki fluktuasi yang kecil. Kebijakan dividen dengan nilai terendah yaitu 0,00 diperoleh dari 55 perusahaan dan nilai tertinggi diperoleh 60 perusahaan dengan nilai 1,00 .

Variabel Harga Saham yang diukur dengan Closing Price (CP) memiliki nilai rata-rata sebesar 3.1666, dengan nilai saham terendah sebesar 1.70 yang diperoleh dari 2 perusahaan yaitu Perusahaan Tiga Pilar Sejahtera Food, Tbk tahun 2012, Perusahaan Indoacidatama tahun 2015 dan tahun 2016. Sedangkan nilai saham tertinggi yaitu 5.38 yang diperoleh dari Perusahaan Delta Djakarta, Tbk tahun 2012, dengan standar deviasi 0.70008 .

Variabel Profitabilitas yang diukur dengan Return on Asset (ROA) memiliki nilai rata-rata sebesar 0.8908, dengan nilai terendah sebesar 0.03 yang diperoleh dari perusahaan EterindonWahanatama tahun 2013. Sedangkan nilai tertinggi yaitu 1.87 yang diperoleh dari perusahaan Multi Bintang Indonesia, Tbk tahun 2013, dengan standar deviasi 0.34636.

Variabel Retained Earnings to Total Asset (RETA) diukur dengan menggunakan laba ditahan dibagi dengan total asset mempunyai nilai rata-rata sebesar 1.4245, dengan nilai terendah sebesar 0.03 yang diperoleh dari perusahaan Eterindo Wahanatama tahun 2013. Sedangkan nilai tertinggi yaitu 1.87 yang diperoleh dari perusahaan Ekadharma International tahun 2013, dengan standar deviasi 0.35635

Variabel Likuditas diukur dengan Current Ratio (CR) diperoleh nilai rata-rata sebesar 2.3502 dengan nilai terendah sebesar 1.71 yang diperoleh dari perusahaan Multi Bintang Indonesia, Tbk tahun 2014. Sedangkan nilai tertinggi yaitu 3.14 yang diperoleh dari perusahaan Intanwijaya Internasional tahun 2013, dengan standar deviasi 0.33554.

Variabel hutang diukur dengan Debt to Asset Ratio (DAR) diperoleh nilai rata-rata sebesar 0.4287 dengan nilai terendah sebesar 0.07 yang diperoleh dari perusahaan Intanwijaya International tahun 2013, tahun 2014, tahun 2016 dan perusahaan Semen Baturaja tahun 2014 . Sedangkan nilai tertinggi yaitu 1.16 yang diperoleh dari perusahaan Budi Starch\&Sweetener tahun 2013, dengan standar deviasi 0.21069 . 


\section{Uji Kecocokan Model Regresi (Overall Model Fit)}

Statistik yang digunakan berdasarkan pada fungsi Likelihood. Likelihood L dari model adalah probabilitas bahwa model yang dihipotesakan menggambarkan data input. Untuk menguji hipotesis nol dan alternatif, L ditransformasikan menjadi -2LogL. Statistik -2LogL kadang-kadang disebut likelihood rasio $\chi^{2}$ statistics, dimana $\chi^{2}$ distribusi dengan degree of freedom $\mathrm{n}-\mathrm{q}$. $\mathrm{q}$ adalah jumlah parameter dalam model. Output SPSS memberikan dua nilai -2LogL yaitu model dengan nilai -2LL pada awal (Block number $=0$ ), model ini hanya memasukkan konstanta dengan nilai -2LL. Pada bagian selanjutnya yaitu Block Number $=1$, model memasukkan konstanta dan variabel independen. Hasil pengujian Overall Model Fit dapat dilihat pada tabel sebagai berikut:

Tabel $2($ Block $0=$ Beginning Block $)$

Iteration History a,b,c

\begin{tabular}{|c|c|c|c|}
\hline & \multirow[t]{2}{*}{-2 Log likelihood } & Coefficients \\
\hline \multicolumn{2}{|c|}{ Iteration } & & Constant \\
\hline Step & 1 & 159,206 & ,087 \\
\hline 0 & 2 & 159,206 & ,087 \\
\hline
\end{tabular}

Sumber: Data Hasil Olahan SPSS 20 (2017)

Tabel 2 Block 1: Method $=$ Enter

Iteration History $\mathrm{a}, \mathrm{b}, \mathrm{c}, \mathrm{d}$

\begin{tabular}{|l|r|r|r|r|r|r|r|r|}
\hline Iteration & \multicolumn{1}{l|}{$\begin{array}{l}\text {-2 Log } \\
\text { likelihood }\end{array}$} & \multicolumn{6}{|c|}{ Coefficients } \\
\cline { 2 - 9 } & 140,375 & $-2,813$ &, 498 & 2,094 &,- 954 &, 196 &, 835 \\
& 139,619 & $-3,130$ &, 602 & 2,665 & $-1,316$ &, 165 & 1,077 \\
& 139,608 & $-3,154$ &, 615 & 2,744 & $-1,370$ &, 156 & 1,110 \\
Step 1 & 139,608 & $-3,155$ &, 616 & 2,745 & $-1,371$ &, 156 & 1,111 \\
& 139,608 & $-3,155$ &, 616 & 2,745 & $-1,371$ &, 156 & 1,111 \\
\hline
\end{tabular}

a. Method: Enter

b. Constant is included in the model.

c. Initial -2 Log Likelihood: 159,206

d. Estimation terminated at iteration number 5 because parameter estimates changed by less than , 001 .

Sumber: Data Hasil Olahan SPSS 20 (2017)

\section{Uji Kelayakan Model Regresi (Hosmer and Lemeshow's)}

Hosmer and Lemeshow's Goodness of Fit Test menguji hipotesis nol bahwa data empiris cocok atau sesuai dengan model (tidak ada perbedaan antara model dengan data sehingga model dapat dikatakan fit).

Tabel 3 Hosmer dan Lemeshow Test

Hosmer and Lemeshow Test

\begin{tabular}{|r|r|r|r|}
\hline $\begin{array}{r}\text { S } \\
\text { tep }\end{array}$ & $\begin{array}{r}\text { Chi- } \\
\text { square }\end{array}$ & Df & Sig. \\
\hline 1 & 7,219 & 8 &, 513 \\
\hline
\end{tabular}


Jika nilai Hosmer and Lemeshow's Goodness of Fit Test Statistics sama dengan atau kurang dari 0.05, maka hipotesis nol ditolak yang berarti ada perbedaan signifikan antara model dengan nilai observasinya. Jika nilai statistik Hosmer and Lemeshow's Goodness of Fit Test lebih besar dari 0.05, maka hipotesis nol tidak dapat ditolak dan berarti model mampu memprediksi nilai observasinya atau dapat dikatakan model dapat diterima karena cocok dengan data observasinya. Pada tabel 3 dapat dilihat hasil output yang menunjukkan bahwa besarnya nilai statistik Hosmer and Lemeshow Goodness-of-fit sebesar 7.219 dengan probabilitas signifikansi 0.513 yang nilainya jauh di atas 0.05. Dengan demikian dapat disimpulkan bahwa model dapat diterima.

\section{Uji Koefisien Determinasi (Nagelkerke's $R$ Square)}

Cox dan Snell's $R$ Square merupakan ukuran yang mencoba meniru ukuran $\mathrm{R}^{2}$ pada multiple regression yang didasarkan pada teknik estimasi likelihood dengan nilai maksimum kurang dari 1 (satu) sehingga sulit diinterpretasikan. Nagelkerke's Square merupakan modifikasi dari koefisien Cox dan Snell untuk memastikan bahwa nilainya bervariasi dari 0 (nol) sampai 1 (satu). Hal ini dilakukan dengan cara membagi nilai Cox dan Snell's $\mathrm{R}^{2}$ dengan nilai maksimumnya.

Tabel 4 Koefisien Determinasi

Model Summary

\begin{tabular}{|r|r|r|r|}
\hline Step & -2 Log likelihood & Cox \& Snell R Square & Nagelkerke R Square \\
\hline 1 & $139,608^{\mathrm{a}}$ &, 157 &, 209 \\
\hline
\end{tabular}

a. Estimation terminated at iteration number 5 because parameter estimates changed by less than ,001.

Sumber: Data Hasil Olahan SPSS 20 (2017)

Uji Signifikansi Simultan (Omnibus Test of Model Coefficients)

Untuk melihat hasil pengujian secara simultan pengaruh variabel independen, maka digunakan tabel Omnibus Test of Model Coefficients.

Tabel 5 Omnibus Test

\begin{tabular}{|rl|r|r|r|}
\multicolumn{4}{|c|}{ Omnibus Tests of Model Coefficients } \\
\hline \multirow{3}{*}{ Step 1 } & Chi-square & Df & Sig. \\
& Step & 19,598 & 5 &, 001 \\
& Block & 19,598 & 5 &, 001 \\
& Model & 19,598 & 5 &, 001 \\
\hline
\end{tabular}

Sumber: Data Hasil Olahan SPSS 20 (2017)

Berdasarkan output diatas diperoleh signifikansi model sebesar, 0.001, karena nilai ini lebih kecil dari 5\% maka dalam penelitian menolak $\mathrm{H}_{0}$ pada tingkat 5\% sehingga dapat disimpulkan bahwa variabel bebas yang digunakan, secara bersama-sama berpengaruh terhadap kebijakann deviden atau minimal ada satu variabel bebas saja yang berpengaruh.

\section{Uji Signifikansi Parameter Individual (Uji Wald)}

Berdasarkan tabel variables in the equation di atas, maka 1 variabel bebas yang signifikan berpengaruh terhadap kebijakan dividen karena hanya variabel tersebut yang memiliki nilai signifikansi yang lebih kecil dari $\alpha=5 \%$. Variabel tersebut ialah profitabilitas dengan nilai sig $=0.003$, sehingga didapatkan model regresi logistiknya sebagai berikut:

$$
\mathrm{DIV}=(\mathrm{P} / 1-\mathrm{P})-3,3155+0.616 \mathrm{X} 1+2.745 \mathrm{X} 2-1.371 \mathrm{X3}+0.156 \mathrm{X} 4+1.111 \mathrm{X5}
$$


Lima variabel independen yang terdiri dari Harga Saham, Profitabilitas, RETA, Likuiditas dan Hutang, hanya ada satu variabel dengan $\mathrm{p}$ value $<0,05$ yaitu variabel profitabilitas yang diproksikan dengan ROA, dapat dilihat bahwa $\mathrm{X}_{2}$ (Profitabilitas) mempunyai nilai signifikansi yaitu $0.003<0.05$ sehingga menolak $\mathrm{H} 0$ atau dapat dikatakan bahwa $\mathrm{X}_{2}$ memberikan pengaruh parsial yang signifikan terhadap kebijakan dividen. Variabel $\mathrm{X}_{1}$ (Harga Saham) mempunyai nilai $0.156>0.05$ yang artinya tidak berpengaruh terhadap kebijakan dividen. Variabel $\mathrm{X}_{3}($ RETA) mempunyai nilai $0.131>0.05$ yang artinya tidak berpengaruh terhadap kebijakan dividen. Variabel $\mathrm{X}_{4}$ (Likuiditas) mempunyai nilai $0.888>0.05$ yang artinya tidak berpengaruh terhadap kebijakan dividen dan variabel $\mathrm{X}_{5}$ (Hutang) mempunyai nilai $0.503>0.05$ yang artinya bahwa variabel hutang juga tidak berpengaruh terhadap kebijakan dividen.

\section{Interpretasi Odds Ratio}

Hasil nilai odds ration dapat dilihat juga melalui tabel Variables in the Equation pada kolom Exp (B) sebagai berikut B1 dengan nilai 0.616, maka diperoleh $\exp (0,156)-1=0,169$ (16.9\%). Hal ini berarti bahwa apabila setiap harga saham $\left(\mathrm{X}_{1}\right)$ meningkat, diperkirakan nilai odds ratio untuk status harga saham akan bertambah sebesar $16.9 \%$ pada variabel profitabilitas $\left(\mathrm{X}_{2}\right)$ yang tetap. $\mathrm{B} 2$ dengan nilai 2.745, maka diperoleh $\exp (0)-1=0(0 \%)$, ini berarti bahwa setiap profitabilitas $\left(\mathrm{X}_{2}\right)$ meningkat, maka diperkirakan nilai odds ratio untuk status RETA $\left(\mathrm{X}_{3}\right)$ akan bertambah sebesar 0\% (dengan kata lain tidak memberikan penambahan nilai odds). B3 dengan nilai -1.371 , maka diperoleh $\exp (0,131)-1=0,140$ (14\%). Hal ini berarti bahwa apabila setiap RETA $\left(\mathrm{X}_{3}\right)$ meningkat, diperkirakan nilai odds ratio untuk status RETA akan bertambah sebesar $14 \%$ pada variabel likuiditas $\left(\mathrm{X}_{4}\right)$ yang tetap. B4 dengan nilai 0.156, maka diperoleh $\exp (0,888)-1=0,431(43,1 \%)$. Hal ini berarti bahwa apabila setiap likuiditas $\left(\mathrm{X}_{4}\right)$ meningkat, diperkirakan nilai odds ratio untuk status likuiditas akan bertambah sebesar 43,1\% pada variabel hutang $\left(\mathrm{X}_{5}\right)$ yang tetap dan $\mathrm{B} 5$ dengan nilai 1.111 , maka diperoleh $\exp (0,503)-1=0,653$ $(65,3 \%)$. Hal ini berarti bahwa apabila setiap likuiditas $\left(\mathrm{X}_{4}\right)$ meningkat, diperkirakan nilai odds ratio untuk status hutang akan bertambah sebesar $65,3 \%$ pada variabel hutang $\left(\mathrm{X}_{5}\right)$.

\section{Pengaruh Harga Saham Terhadap Kebijakan Dividen}

Saham adalah surat berharga (efek) yang memiliki nilai. Setiap investor atau calon investor sudah seharusnya mengetahui harga atau nilai suatu saham yang besarnya berbeda-beda. Harga nominal dan harga perdana adalah harga saham yang akan berhubungan dengan Anda yang membeli saham di pasar perdana, sedangkan harga pembukaan, harga pasar dan harga penutupan akan berkaitan dengan Anda yang bertransakasi di pasar sekunder atau bursa efek. Dalam melakukan transaksi saham, jumlah kelipatan penawaran dan maksimal penawaran serta permintaan tidak bisa sembarangan. Ada prosedur yang mengaturnya sehingga memiliki keseragaman. Pengaturan jumlah kelipatan permintaan dan penawaran ini disebut sebagai fraksi harga saham.

Harga saham secara teknikal akan berfluktuasi sesuai dengan permintaan dan penawaran, akan tetapi kebijakan perusahaan yang berkaitan dengan pembagian dividen tunai juga akan mempengaruhi reaksi investor atau calon investor untuk membeli, menjual atau menahan sahamnya. Reaksi investor dalam membeli, menjual atau menahan saham inilah yang akhirnya akan membuat harga saham berubahubah. Salah satu kebijakan yang harus diambil oleh manajemen perusahaan adalah memutuskan apakah laba yang diperoleh oleh perusahaan selama satu periode akan dibagi semua atau dibagi sebagian untuk dividen dan sebagian lagi tidak dibagi dan dijadikan dalam bentuk laba ditahan (kebijakan dividen). Selain itu juga, biasanya signal perubahan harga saham terjadi dalam hitungan mikro (hari dan jam) dimana perubahan bisa terjadi secara random. Sedangkan kebijakan dividen tidak setiap saat memberikan signal. Signal kuat dari kebijakan dividen nanti pada saat pengumuman atau beberapa waktu sebelum penerimaan atau pembayaran dividen. Sehingga dapat disimpulkan sinkronisasi periode pengamatan antara harga saham dan kebijakan dividen tidak sesuai.

\section{Pengaruh Profitabilitas Terhadap Kebijakan Dividen}

Profitabilitas merupakan kemampuan suatu perusahaan untuk mendapatkan laba (keuntungan) dalam suatu periode tertentu. Profitabilitas adalah kemampuan suatu perusahaan dalam menghasilkan 
keuntungan (profit) pada tingkat penjualan, aset, dan modal saham tertentu. Sedangkan Profitabilitas merupakan kemampuan perusahaan menghasilkan laba (profit) yang akan menjadi dasar pembagian dividen perusahaan. Profitabilitas adalah kemampuan perusahaan untuk mendapatkan laba sehingga memiliki pengaruh pada keputusan pembagian dividen.

Profitabilitas suatu perusahaan akan mempengaruhi kebijakan para investor atas investasi yang dilakukan. Kemampuan perusahaan untuk menghasilkan laba akan dapat menarik para investor untuk menanamkan dananya guna memperluas usahanya, sebaliknya tingkat profitabilitas yang rendah akan menyebabkan para investor menarik dananya. Sedangkan bagi perusahaan itu sendiri profitabilitas dapat digunakan sebagai evaluasi atas efektivitas pengelolaan badan usaha tersebut. Apabila tingkat profitabilitas perusahaan tinggi, maka laba yang dihasilkan perusahaan akan semakin besar dibagikan dalam bentuk dividen kepada pemegang saham. Pihak manajemen akan berusaha untuk memperoleh laba yang sebesar-besarnya guna meningkatkan kemampuan membayar dividen.

Hasil penelitian menunjukkan bahwa profitabilitas berpengaruh signifikan terhadap kebijakan dividen. Artinya peningkatan profitabilitas akan meningkatkan kecenderungan membayar dividen. Dengan adanya peningkatan profitabilitas mempengaruhi kebijakan dividen. Hal tersebut disebabkan oleh tingkat profitabilitas perusahaan tinggi menceminkan laba yang dihasilkan perusahaan semakin besar dan kecenderungan membagikan dividen kepada pemegang saham semakin besar. Pihak manajemen akan berusaha untuk memperoleh laba yang sebesar-besarnya guna meningkatkan kemampuan membayar dividen.

\section{Pengaruh RETA Terhadap Kebijakan Dividen}

Laba Ditahan adalah laba dari operasi dibagikan dan menjadi tambahan penyertaan pemegang saham. Laba Ditahan merupakan jumlah rupiah yang secara yuridis dapat digunakan untuk pembagian dividen. Laba ditahan adalah bagian dari laba bersih perusahaan yang ditahan oleh perusahaan dan tidak dibayarkan sebagai dividen kepada pemegang saham. Uang ini biasanya diinvestasikan kembali ke dalam perusahaan, agar menjadi bahan bakar utama untuk kelangsungan pertumbuhan perusahaan, atau digunakan untuk melunasi hutang-hutang perusahaan. Menghitung laba ditahan dan mempersiapkan laporan laba ditahan adalah bagian yang penting dari pekerjaan seorang akuntan. Laba ditahan (retained earnings) adalah laba bersih yang tidak dibayarkan sebagai dividen tetapi diakumulasikan selama masa usaha perusahaan dan dilaporkan pada bagian kekayaan bersih atau ekuitas dalam neraca. Laba ditahan digunakan untuk investasi kembali dalam bisnis atau untuk melunasi kewajiban keuangan dan bisa bersaldo negatif jika terjadi kerugian. Laba Ditahan (Laba Tidak dibagi) merupakan modal yang berasal dari dalam perusahaan yaitu kumpulan laba dan rugi sampai saat tertentu sesudah dikurangi deviden yang dibagi dan jumlah yang dipindahkan ke rekening modal.

Deviden merupakan nilai pendapatan bersih perusahaan setelah pajak dikurangi dengan laba ditahan (retained earnings) yang ditahan sebagai cadangan perusahaan.Deviden merupakan kompensasi yang diterima oleh pemegang saham, disamping capital gain. Deviden ini untuk dibagikan kepada para pemegang saham sebagai keuntungan dari laba perusahaan. Deviden ditentukan berdasarkan dalam rapat umum anggota pemegang saham dan jenis pembayarannya tergantung kepada kebijakan pimpinan. Hasil penelitian menunjukkan bahwa RETA tidak berpengaruh signifikan terhadap kebijakan deviden. Artinya besarnya laba ditahan tidak menyebabkan kecenderungan perusahaan membayar dividen tinggi dari kondisi dimana laba ditahan kecil. Hal ini dapat dijelaskan berbasis pola kebiasaan membayar dividen perusahaan dan penggunaan laba ditahan. Sebagian besar perusahaan di Indonesia memiliki laba ditahan yang kecil, sehingga sangat dibutuhkan untuk digunakan pada sumber pembiayaan bukan pada pembayaran dividen. Laba yang ditahan ini sangat dibutuhkan karena tidak mengandung kewajiban, misalnya dibandingkan dengan penggunaan hutang. Motivasi ini memiliki dampak tidak signifikan RETA terhadap kebijakan dividen. Sehingga hasil penelitian tersebut tidak sesuai dengan teori life cycle bahwa perusahaan yang saldo laba ditahannya sudah tinggi, biasanya merupakan perusahaan yang berada dalam 
tahap matang, sehingga merupakan kandidat yang baik untuk mendistribusikan kas kepada pemegang saham dalam bentuk dividen.

\section{Pengaruh Likuiditas Terhadap Kebijakan Dividen}

Likuiditas merupakan salah satu rasio keuangan yang digunakan untuk mengukur kemampuan perusahaan untuk memenuhi kewajiban jangka pendeknya. Rasio ini membandingkan kewajiban jangka pendek dengan sumber daya jangka pendek (atau lancar) yang tersedia untuk memenuhi kewajiban tersebut. Dari rasio ini banyak pandangan ke dalam yang bisa didapatkan mengenai kompetensi keuangan saat ini perusahaan dan kemampuan perusahaan untuk tetap kompeten jika terjadi masalah. Likuiditas yang digunakan adalah Current Ratio sebagai rasio untuk mengukur kemampuan suatu perusahaan memenuhi kewajiban jangka pendek. Current Ratio diperoleh dengan menghitung total aktiva lancar dibagi dengan kewajiban jangka pendek. Rasio ini menunjukkan kemampuan perusahaan untuk membayar kewajiban jangka pendeknya dengan menggunakan aktiva lancarnya. Semakin besar Current Ratio menunjukkan semakin tinggi perusahaan dalam memenuhi kewajiban jangka pendek, sehingga kemampuan perusahaan dalam membagikan dividen juga semakin besar. Semakin tingginya Current Ratio juga menunjukkan keyakinan investor terhadap kemampuan perusahaan membayar dividen yang dijanjikan. Hasil penelitian menunjukkan bahwa likuiditas tidak berpengaruh signifikan terhadap kebijakan deviden. Artinya peningkatan dan penurunan likuiditas tidak mempengaruhi kebijakan deviden. Dengan begitu, semakin tinggi likuiditas belum berarti perusahaan tersebut memiliki dana menganggur yang tinggi dan ingin dialokasikan pada kebijakan dividen. Perusahaan yang mempunyai dampak ketidakpastian pembayaran hutang jangka pendek merupakan kondisi perusahaan tersebut berada pada kondisi yang tidak likuid sehingga kas yang masuk sedikit, maka perusahaan akan kesulitan membayar utang dan bahkan kesulitan dalam melakukan kegiatan operasinya. Karena kondisi keuangan yang tidak bagus sehingga kecenderungan perusahaan untuk membagikan dividen menurun.

\section{Pengaruh Hutang Terhadap Kebijakan Dividen}

Semakin tinggi Debt to Asset Ratio semakin berkurang kemampuan perusahaan membayar dividen, sebaliknya semakin turun Debt to Asset Ratio semakin tinggi kemampuan perusahaan membayar dividen. Komitmen perusahaan disektor manufaktur untuk melakukan pembayaran dividen secara teratur menyebabkan kemampuan pembayaran dividen tidak dipengaruhi oleh besar kecilnya hutang perusahaan bahkan kenaikan hutang dapat meningkatkan kemampuan perusahaan membayar dividen selama penggunaan hutang harus selalu diiringi dengan peningkatan laba perusahaan. Hal ini sesuai dengan teori keuangan yang menyatakan jangan lakukan hutang baru jika tidak menghasilkan tambahan laba. Hasil penelitian menunjukkan bahwa hutang tidak berpengaruh signifikan terhadap kebijakan deviden. Artinya peningkatan dan penurunan kebijakan deviden tidak dipengaruhi oleh peningkatan dan penurunan hutang. Hal tersebut diakibatkan oleh karena hutang yang digunakan untuk pembiayaan di perusahaan untuk kepentingan investasi dan investasi yang memilki Investment Opportunity Set (IOS) tinggi maka seharusnya menghasilkan laba yang tinggi dan berpeluang membuat keputusan dividen. Namun kenyataannya hutang tidak optimal digunakan sehingga tidak memiliki kontribusi dalam menghasilkan Earning After Tax (EAT) yang cukup sebagai dasar utama pembagian dividen. Dan hasil penelitian tersebut bertolak belakang dengan teori free cash flow menurut Brigham dan Houston (2010:109) menyatakan bahwa arus kas yang benar-benar tersedia untuk dibayarkan kepada seluruh investor (pemegang saham dan pemilik utang) setelah perusahaan menempatkan seluruh investasinya pada aktiva tetap, produk-produk baru dan modal kerja yang dibutuhkan untuk mempertahankan operasi yang sedang berjalan. 


\section{Kesimpulan}

Berdasarkan hasil penelitian dan pembahasan maka dapat disimpulkan beberapa kesimpulan sebagai berikut:

1. Harga Saham (X1) yang diproksikan dengan Closing Price tidak berpengaruh terhadap kebijakan dividen $(\mathrm{Y})$.

2. Profitabilitas (X2) yang diproksikan dengan ROA berpengaruh terhadap kebijakan dividen (Y).

3. Retained Earnings to Total Assets (X3) tidak berpengaruh terhadap kebijakan dividen (Y).

4. Likuiditas (X4) yang diproksikan dengan Current Ratio (CR) tidak berpengaruh terhadap kebijakan dividen $(\mathrm{Y})$.

5. Hutang (X5) yang diproksikan dengan Debt to Assets Ratio (DAR) tidak berpengaruh terhadap kebijakan dividen (Y).

\section{Keterbatasan Penelitian.}

Dalam penelitian ini terdapat kelemahan dan keterbatasannya yang terdiri dari:

1. Sampel penelitian masih terbatas pada perusahaan manufaktur di Bursa Efek Indonesia, dimungkinkan dengan mengganti perusahaan lain yang lebih luas dan menambah data laporan keuangan untuk melihat faktor-faktor yang mempengaruhi kebijakan dividen.

2. Data atau populasi masih banyak yang tidak lengkap sehingga tidak menjadi sampel penelitian.

\section{Saran} berikut:

Berdasarkan hasil penelitian dan pembahasan, maka dapat dikemukakan beberapa saran sebagai

1. Bagi Investor

Investor perlu memperhatikan tingkat profitabilitas perusahaan memiliki pengaruh positif signifikan, sehingga investor dapat memperoleh keuntungan.

2. Bagi Perusahaan

Bagi perusahaan diharapkan penelitian ini dapat dijadikan informasi pedoman untuk dapat lebih memperhatikan kemampuan perusahaan dalam pengambilan keputusan kebijakan dividen sehingga dapat memberikan keuntungan bagi investor.

3. Bagi Akademisi

Hasil penelitian ini diharapkan dapat menjadi masukan bagi para peneliti selanjutnya untuk dijadikan penelitian yang lebih lanjut lagi, berikut ini hal-hal yang disarankan untuk penelitian selanjutnya.

1. Peneliti selanjutnya diharapkan dapat menambah jumlah tahun penelitian dan jumlah sampel penelitian, agar hasil yang diperoleh dapat menunjukkan pengaruh terhadap kebijakan dividen.

2. Peneliti selanjutnya diharapkan dapat menambah beberapa variabel bebas lain yang dapat mempengaruhi kebijakan dividen, sehingga perkembangan penelitian bermanfaat untuk kepentingan perkembangan ilmu pengetahuan.

\section{Daftar Pustaka}

Ano R., Murni S., dan Rate P. (2014). Pengaruh Current Ratio, ROA, dan ROE terhadap Dividend Payout Ratio (DPR) pada subsektor perbankan yang terdaftar di Bursa Efek Indonesia (BEI) Periode 2009-2013. Jurnal EMBA Vol.2 No.3 September 2014, Hal. 884-894

Baker, M dan Wurgler, J. (2004) A catering theory of dividends. J. Finance. Vol 59, pp. 1125-1165.

Bansaleng, R. D., Tommy, P, dan Saerang, I. S. (2014). Kebijakan Hutang, Struktur Kepemilikan dan Profitabilitas Terhadap Kebijakan Dividen pada Perusahaan Food and Beverage di Bursa Efek Indonesia. Jurnal Riset Ekonomi Manajemen, Bisnis dan Akuntansi.

Brighman, Eugene F, dan Houston, Joel F. (2010). Fundamentals of Financial Managament Dasar Dasar Manajemen Keuangan, Edisi 10. Buku 2: Jakarta Salemba Empat. 
Budiarso Novi dan Pontoh Winston. (2015). Firm's Dividend Decision In Indonesia: Cater or Mature? Journal of Life Economics. Sam Ratulangi University, Faculty of Economic and Business, Indonesia.

DeAngelo H, DeAngelo L dan Stulz R. M. (2006). Dividend policy and the earned/contributed capital mix: a test of the life-cycle theory. Journal of Financial Economics, Vol 81, No 2, pp. 227-254.

DeAngelo H dan DeAngelo L (1990). Dividend policy and Financial Distress; An Empirical Investigation of Troubled NYSE Firms". The Journal of Finance, Vol. 155, pp.1415-1431.

Fama E.F dan French. K.R. (2002). Disappearing Dividend: Changing Firm Characteristics or Lower Propensity to Pay?". Journal of Financial Economics, Vol. 60, pp.3-43.

Lenap, I. (2015) Analisis Model Altman Z -score Dalam Memprediksi Kebangkrutan Pada Perusahaan Pertambangan di Bursa Efek Indonesia, Jurnal Riset Akuntansi Aksioma, Vol 14 No. 1 Juni 2015 Hal 36-54 ISSN 1858-0785.

Sartono. (2005). Manajemen Keuangan Teori dan Aplikasi Edisi Empat. Yogyakarta: BPFE.

Sugiyono. (2012). Memahami Penelitian Bisnis, Pendekatan Kuantitatif, Kualitatif dan R\&D, Bandung: Alfabeta.

Stice, Earls K., Stice, James D., dan Skousen, Fred. (2004) Akuntansi Intermediate. Edisi ke Lima Belas. Terjemahan Safrida R. Parulian dan Ahmad Maulana.Buku Kesatu. Jakarta: Salemba Empat. 